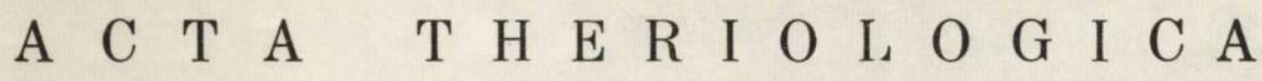

VOL. $18,11: 209-222$

BIAŁOWIEŻA

August, 1973

\author{
January W E I N ER
}

\section{Dressing Percentage, Gross Body Composition and Caloric Value of the Roe-Deer*}

\author{
[With 8 Tables \& 1 Fig.]
}

\begin{abstract}
The dressing percentage, body composition and caloric value of 8 individuals of Capreolus capreolus, killed in winter 1971 and 1972 in Southern Poland, were investigated. The dressing percentage amounted to $65.1 \%$ in adult individuals, and to $58.7 \%$ in young ones. The content of soft tissue in half-carcass was equal to $88 \%$ on the average. Water contents in the whole body is around $64.3 \%$ and is strongly correlated with a rather high fat content ranging from 13.1 to $26.8 \%$ of dry weight. The remaining part of dry weight (mean $65.5^{\circ} \%$ ) consists of proteins and carbohydrates. The mean caloric value of the whole body of roe-deer amounts to $6065.4 \mathrm{cal} / \mathrm{g}$ of dry weight, or to $6937.4 \mathrm{cal} / \mathrm{g}$ ash-free dry weight. After computation for the biomass this value is equal to 2161.1 cal/g. The accumulated fat constitutes energetic reserve, which can reach $10,000 \mathrm{kcal}$ in the average individual of roe-deer.
\end{abstract}

\section{INTRODUCTION}

The roe-deer, Capreolus capreolus ( $\mathrm{L}$ in $\mathrm{n}$ a e u s, 1758), belongs to the animals of high economic value, both as the game providing trophies and valuable meat, as well as an important component of forest ecosystems in Europe. For obtaining the full picture of utility of roe-deer carcasses the data are required on dressing percentage, carcass jointing and energetic value of the meat. In the hunting literature such parameters are scattered, rarely given and difficult to compare on account of nonuniform and not precisely defined methods (Pri or, 1968; M i t c h ell, 1971 , and others).

* Badania były prowadzone w ramach problemu węzłowego 09.1.7., koordynowanego przez Instytut Ekologii PAN. 
Studies on the productivity of roe-deer populations, important for hunting and forest economy, require among others the data on the gross body composition and caloric value of carcasses of the animals. The present study was aimed at the collection of such data on the utility and bioenergetic values of roe-deer bodies.

\section{MATERIAL AND METHODS}

Eight individuals of roe-deer ( 4 bucks, 2 does and 2 fawns), were subjected to the analysis of dressing percentage, body composition and caloric value (Table 1). The buck No 6 was examined only in respect of dressing percentage. The roe-deer were weighed without eviscerating immediately after killing with the accuracy up to $0.5 \mathrm{~kg}$ (live weight). The bodies were paunched and flayed, heads were separated, extremities cut off in the ankle or wrist joints. Then the carcasses

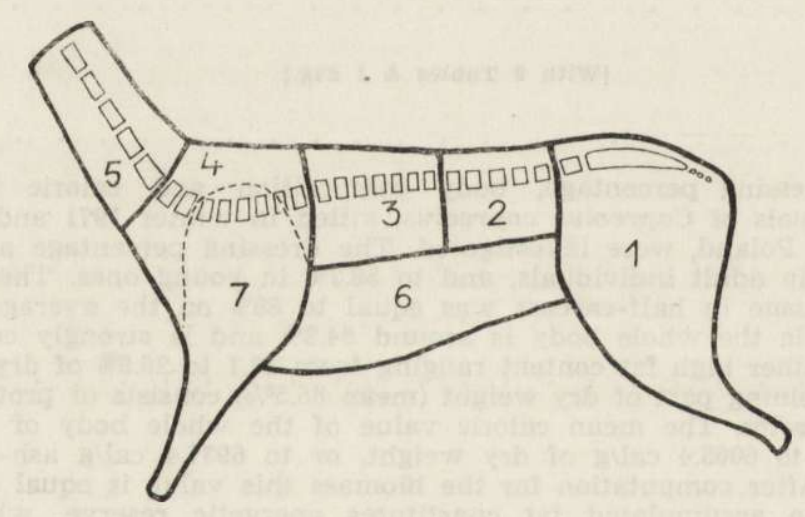

Fig. 1. Division of half-carcass into joint in roe deer.

1 - haunch, 2 - saddle, 3 - entrecote, 4 - chuck, 5 - neck, 6 - brisket with fillet, 7 - shoulder with shin.

were cut into halves along the sagittal plane and divided according to $\mathrm{P}$ a $1 \mathrm{~s} \mathrm{~s}$ on (1939) method (Fig. 1). All parts of the half-carcass, head, skin and viscera were weighed with the accuracy up to $0.01 \mathrm{~kg}$. The empty body weight, used in all further calculations, corresponded to the weight of the whole body with skin, head, viscera and legs, but without intestinal tract and antlers. The ratio of dressed body wieght (= the weight of carcass = venison) to body weight, expressed in per cents, was defined as dressing percentage ( $\mathrm{Szulc}$ et al., 1971). All parts of the right half-carcass were dissected in order to separate soft tissues (muscles, connective tissue and fat) from bones. The loss of water caused by drying during carcass jointing and dissection was corrected after control weighing. All soft parts and bones of each half-carcass were homogenized separately by several passages through electric mills. Similar procedures were employed for the head, legs and intestines. To the "viscera" were reckoned not only the alimentary tract but also all internal organs with mesenteric and perinephric fat.

Water and ash content, as well as caloric value, were determined in representative samples of soft tissues, bones, legs, head and intestines as well as in 
samples of skin, antlers, muscles of the saddle ( $m$. longissimus dorsi) and of haunch ( $m$. quadriceps femoris). The water content was determined by drying in a vacuum oven at $60^{\circ} \mathrm{C}$, or in a conventional laboratory oven at $105^{\circ} \mathrm{C}$. The caloric value and ash content were estimated by combustion of samples in an adiabatic bomb calorimeter KL-3, adopting the procedure described by Górecki (1968). All samples were combusted in 2 or 3 replications.

The samples of all homogenates of each roe-deer were mixed in proportion to their share in dry body weight and then fat content was determined. For this purpose the pooled homogenate was extracted with ethyl ether in a Soxhlet apparatus (S a wicka-Kapusta, 1968). A similar procedure was employed for skin samples.

Knowing the share of particular elements of soft tissues, bones, intestines, head, legs and skin in roe-deer body the total content of water, fat and ash, as well as caloric value for the whole body were calculated. For the obtained mean values standard deviations are given; significance of correlation was estimated by Student $t$-test.

Table 1

Material on outline.

\begin{tabular}{|c|c|c|c|c|}
\hline $\begin{array}{l}\text { Animal } \\
\text { No. }\end{array}$ & Date of slaughter & Sex & Age & $\begin{array}{c}\text { Live weight } \\
\mathrm{kg}\end{array}$ \\
\hline 1 & 24.01 .1971 & 우 & ad. & 26.5 \\
\hline 2 & 5.02 .1971 & $\sigma^{x}$ & ad. & 26.0 \\
\hline 3 & 7.02 .1971 & ㅇ & ad. & 20.0 \\
\hline 4 & 26.02 .1971 & $0^{x}$ & ad. & 25.5 \\
\hline 5 & 8.01.1972 & $\sigma^{\pi}$ & ad. & 27.0 \\
\hline 6 & 8.02 .1972 & $\sigma^{\pi}$ & ad. & 30.5 \\
\hline 7 & 28.12.1971 & $\sigma^{7}$ & $\mathrm{imm}$. & 18.5 \\
\hline 8 & 11.02 .1972 & $0^{x}$ & imm. & 12.5 \\
\hline
\end{tabular}

III. RESULTS

\section{Carcass Jointing and Dressing Percentage}

The relative share of particular joints in the hafl-carcass, and relative share of two half-carcasses in empty body weight (dressing percentage) are given in Table 2. In adult individuals the dressing percentage ranges from 62.6 to $68.0 \%$ (mean: $65.1 \pm 1.8 \%$ ) and is by $6.4 \%$ higher from the dressing percentage fawns, which amounts to $58.7 \%$. The most valuable joints, i.e. haunch and saddle, reach on the average 39.6 and $10.4 \%$ of the half-carcass weight. The percentage share of particular joints is similar in individuals differing in size.

\section{Dissection}

The percentage share of edible soft part (muscles, connective tissue and intramuscular fat) and bones in particular joints is compared in Table 3 


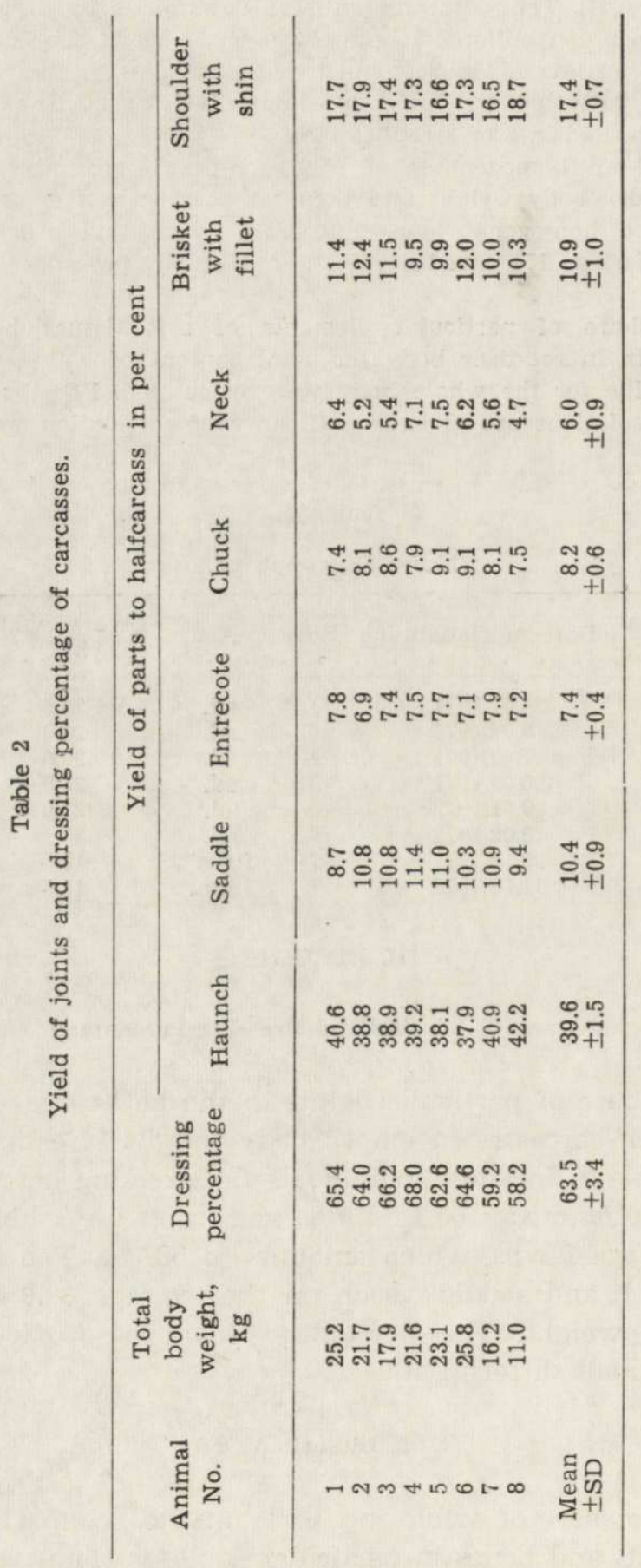


Table 3

Contents of main tissues in joints of carcasses.

\begin{tabular}{lcc}
\hline \multicolumn{1}{c}{ Joints } & $\begin{array}{c}\text { Soft tissues } \\
\text { content in } \% \pm S D\end{array}$ & $\begin{array}{c}\text { Bones content } \\
\text { in } q \pm \text { SD } \\
0\end{array}$ \\
\hline Haunch & $88.2 \pm 1.6$ & $11.8 \pm 1.6$ \\
Saddle & $89.4 \pm 2.9$ & $10.7 \pm 2.8$ \\
Entrecote & $89.1 \pm 3.8$ & $10.9 \pm 3.8$ \\
Chuck & $86.1 \pm 4.2$ & $13.6 \pm 3.9$ \\
Neck & $83.5 \pm 5.4$ & $15.6 \pm 5.6$ \\
Brisket with fillet & $91.6 \pm 2.9$ & $9.0 \pm 2.5$ \\
Shoulder with shin & $84.4 \pm 1.8$ & $15.6 \pm 1.8$ \\
\hline Mean content in & & $11.8 \pm 1.2$ \\
halfcarcass, \pm SD & $87.9 \pm 0.99$ & \\
\hline
\end{tabular}

Table 4

Water content, ash content and caloric value of particular samples of the body of roe deer (means for 7 animals).

\begin{tabular}{|c|c|c|c|c|}
\hline \multirow[b]{2}{*}{ Material } & \multirow{2}{*}{$\begin{array}{l}\text { Water content } \\
\text { in per cent } \\
\text { of fresh weight }\end{array}$} & \multirow{2}{*}{$\begin{array}{l}\text { Ash content } \\
\text { in per cent } \\
\text { of dry weight }\end{array}$} & \multicolumn{2}{|c|}{ Caloric value } \\
\hline & & & $\begin{array}{c}\text { Dry weight } \\
\mathrm{cal} / \mathrm{g}\end{array}$ & $\begin{array}{l}\text { Ash-free } \\
\text { dry weight } \\
\text { cal } / g\end{array}$ \\
\hline 1 & 2 & 3 & 4 & 5 \\
\hline Meat tissue & 68.6 & 4.9 & 5904.8 & 6194.6 \\
\hline Bones & 27.5 & 45.8 & 3321.5 & 5841.0 \\
\hline Skin & 47.5 & 2.7 & 5425.4 & 5543.4 \\
\hline Legs & 35.9 & 24.8 & 4102.5 & 5128.1 \\
\hline Heads & 72.9 & 17.1 & 5704.6 & 6674.3 \\
\hline Intestines & 69.7 & 3.5 & 6603.3 & 6679.5 \\
\hline Muscles of saddle & 69.3 & 5.0 & 5527.7 & 5734.8 \\
\hline Muscles of haunch & 72.0 & 4.3 & 5644.6 & 5945.6 \\
\hline Antlers & $-^{*}$ & 39.4 & 1695.3 & 4281.8 \\
\hline
\end{tabular}

* Not measured

It appears that almost $88 \%$ of the half-carcass weight fall for soft tissues. They represent on the average $56.7 \pm 3.0 \%$ of total body weight, with the mean equal to $57.3 \%$ for adult individuals and to $51.7 \%$ for fawns.

\section{Body Composition}

On the basis of individual determinations of water content in particular homogenates (Table 4, column 2) the amount of water in the whole body is calculated (Table 5 , column 2). Water constitutes on the average $64.3 \pm$ $\pm 4.3 \%$ of the total body weight. Fat represents the most variable constituent of body dry weight. The share of ether extract in dry mass ranges from 13.1 to $26.8 \%$ (Table 5 , column 4). Changes in the content 
Table 5

Computed gross body composition of the whole roe deer, in per cent.

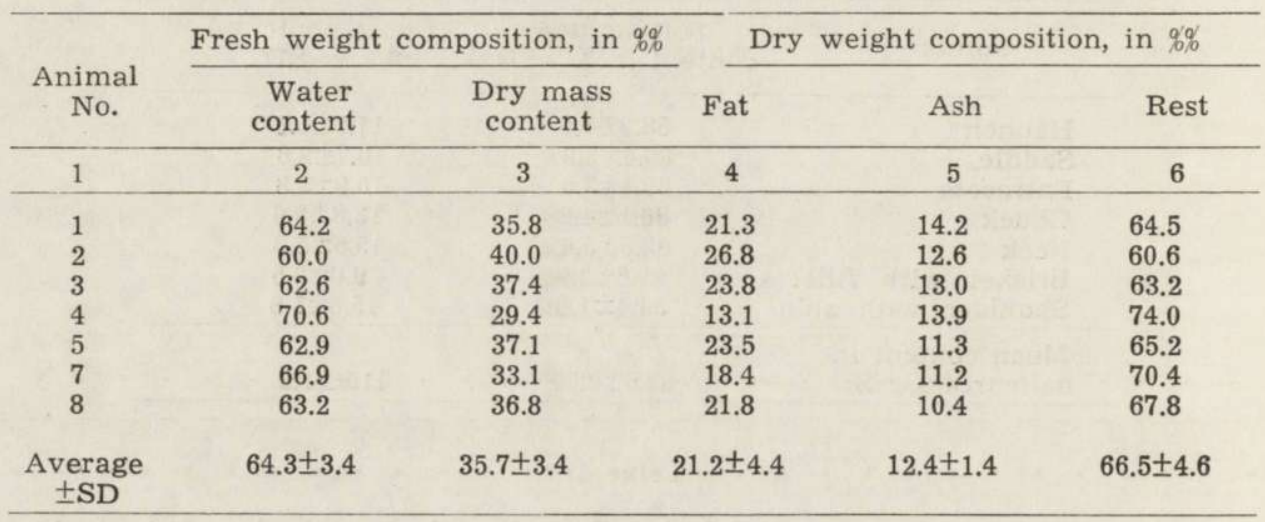

Table 6

Computed caloric values of the whole roe deer body.

\begin{tabular}{cccc}
\hline $\begin{array}{c}\text { Animal } \\
\text { No. }\end{array}$ & $\begin{array}{c}\text { Dry weight } \\
\text { cal/g }\end{array}$ & $\begin{array}{c}\text { Ash-free } \\
\text { dry weight } \\
\text { cal/g }\end{array}$ & $\begin{array}{c}\text { Fresh weight. } \\
\text { cal/g }\end{array}$ \\
\hline 1 & 5926.2 & 7032.8 & 2081.5 \\
2 & 5953.9 & 6810.5 & 2384.3 \\
3 & 5928.1 & 6811.9 & 2215.6 \\
4 & 5809.2 & 6743.3 & 1710.5 \\
5 & 6574.3 & 7410.4 & 2441.9 \\
7 & 6055.4 & 6822.9 & 2007.3 \\
8 & 6211.1 & 6929.7 & 2286.8 \\
Average \pm SD & $6065.4 \pm 180.0$ & $6937.4 \pm 229.3$ & $2161.1 \pm 248.0$ \\
\hline
\end{tabular}

of water and fat are mutually correlated $(r=-0.98, P<0.001)$, and the relationship corresponds to the rectilinear regression: $Y=102.83-1.268 X$ (where $Y=$ per cent of fat in dry mass, $X=$ per cent of water in biomass).

The ash content in the whole body dry mass, calculated also on the basis of single determinations in particular homogenates (Table 4, column 3) reaches on the average $12.4 \pm 1.4 \%$ (Table 5 , column 5). The remaining constituents of body dry weight (mainly proteins with a small admixture of carbohydrates) represent on the average $66.5^{0} \%$ (Table 5 , column 6).

\section{Caloric Value}

The mean caloric values of particular homogenates are compared in Table 4, column 4 and 5 . The highest caloric value was found for the 
homogenate of viscera ( $6603.3 \mathrm{cal} / \mathrm{g}$ dry weight). The energetic value of the soft parts homogenate of half-carcass amounts on the average to $5904.8 \mathrm{cal} / \mathrm{g}$ dry weight. The caloric values of dry mass in particular homogenates (Table 4, column 4) show considerable differences on account of variable contents of mineral constituents (ash content). After computing for ash-free dry wt. the caloric values are more similar, since depend only on the proportion of fat to protein and carbohydrates. A relatively high caloric value of the ash-free dry wt. was found for bones (5841.0 $\mathrm{cal} / \mathrm{g}$ ). This is caused by a high fat content in the long bone marrow.

Single data on the caloric values of samples from different body parts of particular roe-deer were used for calculation of the mean energy value of the whole body (Table 6). The energy equivalent of dry weight amounts of the average to $6065.4 \mathrm{cal} / \mathrm{g}$. The caloric value of biomass is well correlated with the content of ether extract in the body dry weight $(r=0.92,0.001<P<0.01)$. The determined caloric values of the saddle and haunch meat reach respectively 5527.7 and $5644.6 \mathrm{cal} / \mathrm{g}$ dry wt. The caloric value of antlers amounts to $1695.3 \mathrm{cal} / \mathrm{g}$ dry wt. After taking into account a rather high content of mineral salts (ash) present in the antlers the remaining part correspond mainly to proteins of a low caloric value. The caloric value of ash-free dry wt. for antlers amounts to $4281.8 \mathrm{cal} / \mathrm{g}$.

\section{DISCUSSION}

\section{Dressing Percentage and Dissection}

The dressing percentage of roe-deer, defined as the relative ratio of dressed body weight (venison) to empty body weight, amounted to $65.1 \%$ on the average in eight examined animals. According to Prior (1968) the dressing percentage of roe-deer in England is equal to $55 \%$ for bucks in summer and to $58 \%$ for does in winter. However, this author does not include neck to dressed body weight. After taking this into account the dressing percentage will increase in bucks to $58.3 \%$ and in does to $61.5 \%$ i.e. values similar to those obtained in the present study. The dressing percentage of European hare (Lepus europaeus Pallas), estimated by Tilgner (1949) as $66.1 \%$, is close to the values reported for roe-deer. Slightly lower values were found by many authors as dressing percentage for different Ungulates used for hunting (Table 7). These data are, however, difficult to be accurately compared on account of variable definitions of dressing percentage and dressed body weight. Among farm animals sheep exhibits a rather similar body size and hence may be used for comparison of dressing percentage. This 


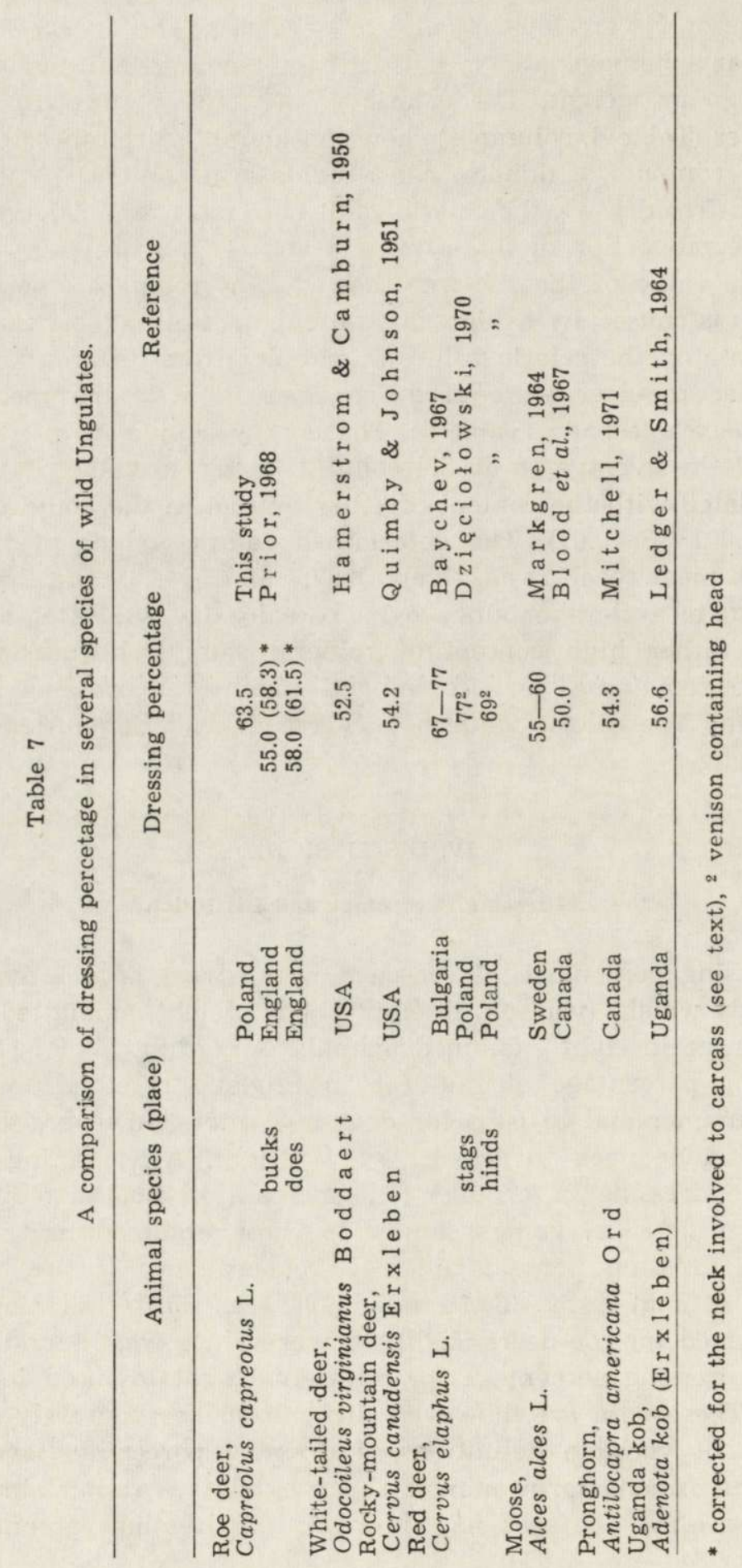


value determined on a large material of sheep is very variable, in the range from 42.3 to $52.7 \%$, and depends on both the degree of fatness and the amount of fleece ( $\mathrm{J}$ e $ł \mathrm{ow}$ icki, 1960). A considerable weight of skin and fleece in a sheep decreases the coefficient of dressing percentage.

Many authors reported the rise in the dressing percentage with age and body weight of killed animals (cf. M i t chell, 1971; Tilg ner, 1949, 1950). Among 8 examined roe-deer the youngest and smallest individuals showed also the lowest dressing percentage. However, the material is too scarce for any further analysis of this relationship.

During carcass jointing a standard method used for sheep was employed ( $\mathrm{P}$ áls son, 1939). This method is very convenient for practical purposes. The dissection allowed to estimate the total amount of soft edible tissues in the half-carcass and the whole roe-deer body. The mean content of soft tissues in the half-carcass amounting to $88 \%$ was very similar in animals of different size, but after expressing as percentage of total body weight it appears to be slightly higher in large animals $(57.9 \%)$ than in young ones $(55.9 \%)$. The mean content of soft tissues in the whole body amounted to $56.7 \%$. H akonson \& Whic$\mathrm{k}$ l e r (1971) investigated the content of muscles and bones in the body of mule deer, Odocoileus hemionus ( $\mathrm{R}$ a f in esque, 1817). The content of muscles in the whole body weight of this animal amounted to barely $46.9 \%$, since the muscles were cleared of connective and fat tissues. Also in this species the content of muscles increased with age and total body weight.

\section{Body Composition and Energetic Reserves}

In the present study the roe-deer body was divided into fractions, which were analysed separately in respect of gross body composition and caloric value. The homogenization of the whole carcass employed commonly in the studies of small animals would be very cumbersome in the case of roe-deer. It would be also difficult to obtain sufficiently uniform homogenate and representative samples for analysis. This is associated among others with different mechanical properties of individual tissues. For this reason soft tissues should be homogenized in an electric mincer, while for hard tissues (bones) a grind mill is required.

In comparison with the gross body composition of wild free-living mammals, e.g. small rodents or European hare, the bodies of roe-deer are characterized by more variable content of water and fat. For example the mean content of fat in the bank vole body, Clethrionomys glareolus ( $\mathrm{Sch} \mathrm{reber}$ ), ranges only between 10.4 and $14.0 \%$ (S a w i c ka-K a- 
pusta, 1972), while in European hare it amounts on average to $19.41 \pm 1.7 \%$ (M y r ch a, 1968). The content of fat in the roe-deer body amounts on average to $21.2 \pm 4,4 \%$, ranging between 13.1 and 26.8 per cent of dry wt. A considerable individual variability in the fat content of roe-deer body is related to different state of examined animals. Roe-deer may accumulate fat as energetic reserve and utilize it in a period of food scarcity. Comparing the individuals with the lowest and the hihgest fat content (26.8 and $13.1 \%$ dry wt., respectively), it can be concluded that the amount of fat corresponding to at least $13.7 \%$ of body dry weight (i.e. nearly $5 \%$ of biomass) may constitute a considerable reservoir of energy. In the average roe-deer weighing approximately $20 \mathrm{~kg}$ such amount of fat corresponds to approximately 10,000 kcal. Drożd ż \& Osiecki (1973) studied in roe-deer the consumption and digestibility of natural food in the winter period and found a poor digestibility of browse in this period. Assuming that no other food is then available, the daily deficite of energy consumption may reach $400 \mathrm{kcal}$. Hence the mean fat reserve may cover such deficite for as much as 25 days. $\varnothing \mathrm{r}$ is ts land (1970) found in the reindeer (Rangifer tarandus platyrhynchos, V rolik) an even higher fat reserve, amounting to $14 \%$ of its biomass.

Ash content in the weight of roe-deer body ( $12.4 \%$ on the average) is rather similar to that found in different species of small mammals $(10.2-13.7 \%$, Gó r e c ki, 1965), and in European hare $(12.38 \%$, M y r$\mathrm{ch}$ a, 1968).

\section{Caloric Value}

The caloric value of roe-deer body is on the average slightly higher from the corresponding values of different small rodents $(1502 \mathrm{cal} / \mathrm{g}$ of biomass; G ó r e c k i, 1968) and of European hare (1873.9 cal/g of biomass; Myrcha, 1968). The high caloric value of roe-deer body, reaching $2161.1 \mathrm{cal} / \mathrm{g}$ of biomass, results from its considerable fatness. All the examined animals were shot in winter when they can achieve the maximum fatness. The energetic values for the whole body of roe-deer cannot be compared with analogous data for farm animals since the data available in the literature refer to edible parts only. In the examined roe-deer edible parts are represented in principle by the soft tissue homogenate (Table 4). This can be compared with the values in food composition tables for game and farm animals (Table 8). The comparison indicates that both water content and caloric values of edible parts of a roe-deer shot in winter in a good state are very close to lean sheep carcass or fat veal. Hence apart from original taste the roe-deer meat 
is of good quality in respect of fatness. In Table 8 also the data for roe-deer meat are given after Szczygie 1 (1972). The low caloric value and high water content allow to suppose that the values refer to animals killed in summer, when their fantness is much smaller.

The results of this study can be useful in the investigations of productivity of roe-deer population. The body caloric value is an essential parameter for calculating the net production which is included in the balance of energy flow through a population (P etrides et al., 1968). For such computations the energetic value of roe-deer biomass in the winter period, equal to $2.16 \mathrm{kcal} / \mathrm{g}$, is recommended. In summer one can expect a lower mean fatness, hence the mean year caloric value of biomass will be also lower. Assuming that roe-deer fatness in summer is similar to the minimum fatness observed in winter, then the figure of $1.9 \mathrm{kcal} / \mathrm{g}$ can be used for the mean year caloric value of the biomass.

Table 8

A comparison of water content, ash content and caloric value of the meat of roe deer and some domestic animals.

\begin{tabular}{|c|c|c|c|c|}
\hline & Meat & $\begin{array}{l}\text { Water content } \\
\text { (per cent of } \\
\text { fresh weight) }\end{array}$ & $\begin{array}{l}\text { Ash content } \\
\text { (per cent of } \\
\text { fresh weight) }\end{array}$ & $\begin{array}{l}\text { Caloric value } \\
\text { of fresh weight } \\
(\mathrm{cal} / \mathrm{g})\end{array}$ \\
\hline Roe deer & venison $^{1}$ & 68.6 & 1.5 & 1854.1 \\
\hline Roe deer & venison $^{2}$ & 75.8 & 1.1 & 1080.0 \\
\hline \multirow[t]{3}{*}{ Mutton ${ }^{2}$ : } & lean & 69.0 & 1.0 & 1910.0 \\
\hline & medium fat & 56.3 & 0.8 & 3080.0 \\
\hline & fat & 46.4 & 0.7 & 4070.0 \\
\hline \multirow[t]{3}{*}{ Veal ${ }^{2}$ : } & lean & 74.0 & 1.0 & 1230.0 \\
\hline & medium fat & 71.0 & 1.0 & 1560.0 \\
\hline & fat & 68.0 & 1.1 & 2080.0 \\
\hline
\end{tabular}

1 calculated from the Table $4,{ }^{2}$ after S z c z y gie 1 et al., 1972.

The whole energetic value of the adult roe-deer body depends on the animal body size and condition and may be comparised within $30-60$ thousand kcal, while that of half-year-old fawn - around $20-35$ thousand kcal. In Southern Poland (Niepolomicka Forest), the mean weight of adult roe-deer amounts in winter to $23 \mathrm{~kg}$, and half-year-old fawn to $15 \mathrm{~kg}$ (B o be k B., unpubl. data). Hence the mean energetic values reach 49.5 and 32.4 thousand kcal., respectively. The antlers rebuilt every year by the bucks are equivalent to $170-850 \mathrm{kcal}$, depending on their size (100 to $500 \mathrm{~g})$. The caloric value of edible tissues to roe-deer constitutes on the average approximately $47 \%$ of total energy value of the body (in small animals $42.8 \%$, in large ones - 51.0\%). The energy reserves accumulated under the form of fat may hence reach $23-25 \%$ of the total caloric value of the roe-deer body. 
Both the fatness and caloric value of the roe-deer body undergu changes in the year cycle, similarly to other deers (e.g. in red deer, Cervus elaphus L.; M itche 11 et al., 1970). Such seasonal changes in the roe-deer are not sufficiently known as yet.

Acknowledgements: I am very grateful to Dr. B. Nowo s a d, Institute of Applied Zoology, Academy of Agriculture, Kraków, for his valuable help in carcass jointing, as well as to Dr. W. Grodzińs $\mathrm{ki}$ for critical examination of the manuscript.

\section{REFERENCES}

1. B a y chev S., 1967: Randemanat na mesoto od blagorodnija jelen. Gorska stopanstvo, 11: $36-38$, Sofia.

2. Blood D. A., McGills J. R. \& Lovaas A. L., 1967: Weights and measurements of moose in Elk Island National Park, Alberta. Canadian Field Naturalist, 81, 4: 263-269.

3. Drożdz A. \& Osiecki A., 1973: Consumption and digestibility of natural food in roe-deer. Acta theriol., 18: 81-91.

4. Dzięciołowski R., 1970: Relations between the age and size of red deer in Poland. Acta theriol., 15, 17: 253-268.

5. Górecki A., 1965: Energy values of body in small mammals. Acta theriol., 10, 23: $333-352$.

6. G 6 recki A., 1967: Caloric values of the body in small rodents. [In: "Secondary Productivity of Terrestrial Ecosystems", Ed. Petr use wicz K.], PWN, 315321. Warszawa-Kraków.

7. G6recki A., 1968: The adiabatic bomb calorimeter. [In: "Methods of Ecological Bioenergetics«, Handbook of IBP Training Course, Eds. Grodziński \& Klek ow s ki R.] :134-144. PWN, Warszawa-Kraków.

8. Hakonson T. E. \& Whickler F. W., 1971: The contribution of various tissues and organs to total body mass in the mule deer. J. Mammal., 52, 3: $628-630$.

9. Hamerstrom F. N., Jr. \& Camburn F. L., 1950: Weight relationship in the George reserve deer herd. J. Mammal., 31, 1: 5-17.

10. J e łow iecki S. 1960: Owczarstwo wielkostadne. 1-294. PWRiL, Warszawa.

11. Ledger H. P. \& Smith N. S., 1964: The carcass and body composition of the Uganda kob. J. Wildl. Mgmt., 28, 4: 827-839.

12. M a rkgreen G., 1964: Puberty, dentition and weight of yearling moose in a Swedish county. Viltrevy, 2, 7: 409-417.

13. Mitchell B., McCovan D., Sturton G., Stevenson J. A., McLennan A. B., Jenkins W., 1970: Annual cycles of condition and body composition in selected classes of red deer on the Isle of Rhum. [In: *The nature conservancy research in Scotland «. Report for 1968-1970] 12: 43-46. Howie \& Seath Ltd. Edinburgh.

14. Mitchel1 G. J., 1971: Measurements, weights and carcass yields of pronghorns in Alberta. J. Wildl. Mgmt., 35, 1: 76-85.

15. Myrcha A., 1968: Caloric value and chemical composition of the body of the European hare. Acta theriol., 13, 5: 65-71.

16. Øristsland N. A., 1970: Fett reserver hos Svalbardreinen. Fauna, 23: 106-107. 
17. Pálss on H., 1939: Meat quolities in the sheep with special reference to scottish breeds grosses. J. Agric. Sci., 29: 544.

18. Petrides G. A., Golley F. B., Brisbin I L., 1968: Energy flow and secondary productivity. [In: "Productivity of Large Herbivores" Eds. Golle y F. B. \& Buechner H. K.] IBP Handbook 7, 2: 9-17. Blackwell Sci. Publ., Oxford-Edinburgh.

19. Quimby D. C. \& Johns on D. E., 1951: Weights and measurements of Rocky Mountain elk. J. Wildl. Mgmt., 15, 1: 57-62.

20. Prior R., 1968: The roe deer of Cranborne Chase. 1-119. Oxford Univ. Press, London.

21. Sawicka-Kapusta K., 1968: Fat extraction in the Soxhlet apparatus. [In: "Methods of Ecological Bioenergetics«, Handbook of IBP Training Course, Eds. Grodziński W. \& Klekowski R.] 145-149. Warszawa-Kraków.

22. Sawicka-Kapusta K., 1972: Changes of caloric value and gross body composition during the postnatal development of bank vole. $\mathrm{Ph}$. D. thesis, Jagiellonian University, Cracow, 1-32. [In Polish].

23. Szczygiel A., Klimczak Z., Piekarska J. \& Muszkatowa B., 1972: Tabele składu i wartości odżywczych produktów spożywczych. PZWL, Warszawa.

24. Szulc M., Tropilo J. \& Krasińska M., 1971: Dressing percentage and utility value of the meat of European bison and domestic cattle hybrids. Acta theriol., 16, 26: 413-422.

25. Tilgner D. J., 1949: Wartość przetwórcza zajęcy. Łowiec pol., 11(972): 19-22. $19-22$.

26. Tilgner D. J., 1950: Wydajność i selekcja zajęcy. Łowiec pol., 10(983): 12-16. 12-16.

Accepted, March 20, 1973.

Department of Animal Ecology,

Jagiellonian University,

Krupnicza 50, 30-060 Kraków, Poland.

January WEINER

WYDAJNOSC POUBOJOWA, SKEAD CIA£A I WARTOSC KALORYCZNA SARNY

Streszczenie

Zbadano wydajność poubojową, skład ciała i wartość energetyczną 8 osobników sarn, Capreolus capreolus (L.), ubitych w ciągu zimy 1971 i 1972 na terenie woj. krakowskiego (Tabela 1). Tusze sarn rozbierano metodą Páls s on a (1939) (Fig. 1). Wydajność poubojowa (stosunek ciężaru obu półtusz do całkowitego ciężaru ciała, wyrażony w \%) osiąga u osobników dorosłych $65,1 \%$, zaś u młodych $58,7 \%$ (Tabela 2). Zawartość jadalnych, miękkich tkanek (mięśnie, tkanka łączna i tluszcz śródmięśniowy) w półtuszy osiągała średnio prawie $88 \%$. Zawartość wody w całym ciele wahała się wokb́ł $64.3 \%$ (Tabela 3, kolumna 2). Jest ona silnie skorelowana Acta theriol. 15 
ujemnie $(r=-0,98, P<0,001)$ z zawartością tłuszczu, która jest stosunkowo wysoka I średnio osiąga $21,2 \%$ suchej masy ciała (Tabela 5, kolumna 4). Popiół przeciętnie stanowi $12,4 \%$ suchej masy (Tabela 5, kolumna 5), białko i niewielka ilość węglowođanów składają się na pozostałe $65,6 \%$ suchej masy ciała (Tabela 5 , kolumna 6). Wartość kaloryczna suchej masy ciała wynosiła przeciętnie $6065,4 \mathrm{cal} / \mathrm{g}$, zaś suchej masy bez popiołu $6937,4 \mathrm{cal} / \mathrm{g}$. Wartość kaloryczna biomasy w zimie osiąga 2161,1 cal/g, jest więc wyższa niż u drobnych ssaków i u zająca (Tabela 6). Latem wartość kaloryczna ciała sarny jest zapewne nieco niższa, ze względu na mniejsze otłuszczenie. Srednia wartość kaloryczna wszystkich części jadalnych ciała sarny osiąga 1854,1 cal/g biomasy, co odpowiada kaloryczności tłustego mięsa cielęcego lub chudej baraniny. Wartość energetyczna całego ciała sarny w warunkach Polski Południowej osiąga przeciętnie zimą 49,5 tys. kcal, zaś u koźląt półrocznych 32,4 tys. kcal. Rezerwy energetyczne zgromadzone u sarny w postaci tluszczu mogą osiągać u dorosłego osobnika około 10 tys. kcal, co pozwala na pokrycie zimowego deficytu pokarmowego w ciągu około 25 dni. 